\title{
Risk and Protective Factors for Breast Cancer in Midwest of Brazil
}

\author{
Lívia Emi Inumaru, ${ }^{1}$ Maíra Irineu Gomes Duarte Quintanilha, ${ }^{2}$ \\ Érika Aparecida da Silveira, ${ }^{1}$ and Maria Margareth Veloso Naves ${ }^{1}$ \\ ${ }^{1}$ Nutrition Faculty, Federal University of Goiás, Rua 227, Quadra 68, s/nº, Setor Leste Universitário, 74605-080 Goiânia, GO, Brazil \\ ${ }^{2}$ Department of Agricultural, Food and Nutritional Science, University of Alberta, 4-10 Agriculture/Forestry Centre, Edmonton, AL, \\ Canada T6G $2 P 5$
}

Correspondence should be addressed to Maria Margareth Veloso Naves, mnaves@fanut.ufg.br

Received 21 December 2011; Revised 27 February 2012; Accepted 27 February 2012

Academic Editor: Pam R. Factor-Litvak

Copyright (c) 2012 Lívia Emi Inumaru et al. This is an open access article distributed under the Creative Commons Attribution License, which permits unrestricted use, distribution, and reproduction in any medium, provided the original work is properly cited.

Patterns of physical activity, body composition, and breastfeeding are closely related to health and are influenced by environmental, economic, and social factors. With the increase of sedentary lifestyle and overweight, many chronic diseases have also increased, including cancer. Breast cancer is the most common cancer in women worldwide, and the knowledge of its risk and protective factors is important to the adoption of primary prevention strategies. We aimed to investigate some risk and protective factors for breast cancer among women from Midwest Brazil. It is a case-control study of outpatient basis, carried out with 93 breast cancer cases and 186 controls. Socioeconomic, gynecological, anthropometric, and lifestyle variables were collected, and odds ratios (ORs) values were estimated (significance level, 5\%; confidence interval (CI), 95\%). Per capita income equal to or lower than $1 / 2$ Brazilian minimum wage $(\mathrm{OR}=1.88$; $\mathrm{CI}=1.06-3.29)$, residence in rural area $(\mathrm{OR}=4.93$; $\mathrm{CI}=1.65-14.73)$, and presence of family history of breast cancer $(\mathrm{OR}=5.38 ; \mathrm{CI}=1.46-19.93)$ are risk factors for breast cancer. In turn, physical activity (past 6 months) $(\mathrm{OR}=0.23 ; \mathrm{CI}=0.10-0.55)$ and leisure physical activity at 20 years old $(\mathrm{OR}=0.13 ; \mathrm{CI}=0.03-0.54)$ are protective factors for the disease in women who live in Midwest of Brazil.

\section{Introduction}

Around the world, populations have changed rural areas for cities, becoming more sedentary and consuming great amounts of industrialized foods and beverages, which have contributed for the increase of obesity and chronic diseases, such as cancer. These changes began in Europe, North America, and other countries that became industrialized in XIX century. In recent decades, there was acceleration in urbanization process around the world, especially in lowmiddle-income countries, like Brazil. Patterns of physical activity, body composition, and breastfeeding are determined by environmental (urbanization, urban planning, which includes transport systems), economic (social status), and social (education level) factors, influencing, thus, the occurrence of several types of cancer $[1,2]$.
Breast cancer is the most common cancer in women worldwide and has been associated with higher socioeconomic status and urbanized populations [2, 3]. Family history of breast cancer and gynecological variables, such as early menarche, late menopause, not bearing children, and late first pregnancy are well established risk factors for breast cancer $[2,4]$. Besides these variables, according to the World Cancer Research Fund (WCRF) and the American Institute for Cancer Research (AICR) [2], drinking alcoholic beverages is a risk factor, whereas breastfeeding is a protective factor for breast cancer. However, regarding the body fatness, adult attained height, abdominal fatness, adult weight gain, and physical activity, the evidences are not sufficiently clear [2]. Body fatness is a convincing risk factor only for postmenopausal breast cancer, and the protective influence of physical activity is not convincing yet [2]. 
TABLE 1: The inclusion and exclusion criteria of women with breast cancer (cases) and their controls (Midwest, Brazil, 2008-2010).

\begin{tabular}{|c|c|c|}
\hline & Inclusion criteria & Exclusion criteria \\
\hline Cases & $\begin{array}{l}\text { Histopathological breast cancer diagnosis given in } \\
\text { the same data or within a week of the interview } \\
\text { No prior treatment (e.g., surgery, radiotherapy, } \\
\text { chemotherapy) } \\
\text { No previous history of cancer in other parts of the } \\
\text { body } \\
\text { Breast cancer stage III or lower } \\
\text { Agreement of signing written informed consent }\end{array}$ & $\begin{array}{l}\text { No breast cancer } \\
\text { Already in treatment } \\
\text { Previous history of other types of cancer } \\
\text { Advanced cancer (stage IV)* } \\
\text { Women who had received counseling from a } \\
\text { registered dietitian } \\
\text { Pregnant or puerperal women } \\
\text { Mental or physical disabilities that would hinder } \\
\text { the interview }\end{array}$ \\
\hline Controls & $\begin{array}{l}\text { Age-matched subjects ( } \pm 5 \text { years) } \\
\text { No medical history of cancer } \\
\text { Agreement of signing written informed consent }\end{array}$ & $\begin{array}{l}\text { Medical history of breast disease or any type of } \\
\text { cancer } \\
\text { Women who had received counseling from a } \\
\text { registered dietitian } \\
\text { Pregnant or puerperal women } \\
\text { Mental or physical disabilities that would hinder } \\
\text { the interview }\end{array}$ \\
\hline
\end{tabular}

\footnotetext{
* Stage IV cases were excluded because these patients probably would have more pronounced clinical symptoms, such as significant weight change, that could impair data qualify.
}

Most studies on the determinant factors for breast cancer, especially related to physical activity, have been conducted in high-income countries [5-8]. Thus, some risk factors pointed by the WCRF and the AICR [2] may be different from that found in low-middle-income countries, such as Brazil, which has a different epidemiological profile. In most of Latin American countries, the transition experience is unlike that of the developed countries and is distinguished by the coexistence of infectious diseases and chronic diseases as important causes of death. This epidemiological profile is called "transition polarized model" [9].

Furthermore, in Brazil and other Latin American countries, there are few recent analytical studies on the risk and protective factors for breast cancer. According to a 2009 report by Brazilian National Cancer Institute [4], in Goiânia, capital of Goiás state (Midwest of Brazil), the estimated risk for breast cancer was 51.87 new cases per 100000 women, which was close to the national mean estimate (49.27 new cases per 100000 women). Knowledge of risk and protective factors among populations is important to identify groups that are more susceptible and to develop strategies for primary prevention [10]. Thus, the objective of this study was to investigate some risk and protective factors for breast cancer among women from Midwest of Brazil and with recent diagnosis of breast cancer.

\section{Material and Methods}

2.1. Material. This outpatient-based case-control study was conducted in 2 reference public hospitals of Goiânia, capital of Goiás state, situated in Midwest of Brazil. Cases were interviewed at the Conjunctive Tissue Sector and Gynecology and Breast Clinic of Araújo Jorge Hospital (HAJ), a public institution that specializes in the prevention, diagnosis, and treatment of cancer, that provides health service to people from throughout Midwest of Brazil. Cases were also interviewed at the Breast Service of the General Hospital of the Federal University of Goiás (Hospital das Clínicas da Universidade Federal de Goiás, HC/UFG). Controls were selected among users of the Gynecology Clinic at HC/UFG. Both hospitals (HAJ and HC/UFG) attend to Unique Health System (SUS) users, which have a similar socioeconomic profile.

To calculate the sample size, the following criteria were considered: significance level of $5 \%$, study power $(1-\beta)$ of $80 \%, 2$ controls for each case, an odds ratio (OR) of 2.5 [12], and a prevalence of risk for consumption of alcohol among controls of $14.4 \%$ [13]. According to these parameters, the total sample must include 186 controls and 93 cases of women with breast cancer. The inclusion and exclusion criteria (cases and controls) are shown in Table 1.

This study was approved by the ethics committees of UFG (protocol no. 026/08) and Araújo Jorge Hospital (protocol no. 019/08). Written informed consent was obtained from all participants.

2.2. Data Collection. Data were collected between May 2008 and June 2010, through a questionnaire that had been previously tested in a pilot study. This questionnaire included socioeconomic variables (per capita income-in American dollar-education level, and area of residence), family history of cancer and breast cancer, gynecological variables (number of children, age at first pregnancy, age of menarche, and age of menopause), breastfeeding information, anthropometric measures, alcoholic drink consumption, physical activity, and smoking habit. Questions about alcoholic drink consumption, physical activity, and smoking habit were asked regarding the 6 months prior to the interview date. Data on body weight and physical activity were also investigated considering the young age (20 years old) [14].

Interviewees provided data on occurrence and duration of breastfeeding (in months) for each of their children, which were added up to provide lifetime duration of breastfeeding. Anthropometric variables included height, current and 
previous (at 20 years-old) body weight, waist circumference, current and previous body mass index (BMI), and adult weight gain. The first 3 variables were obtained according to the protocol reported by Lohman et al. [15]. Before data collection, these measures were standardized among interviewers, according to Habicht [16]. The cut-off points used to classify nutritional status and waist circumference were established based on the World Health Organization [11]. Weight gain in adulthood was estimated by the difference between weight at the time of research and weight at 18-20 years old [14].

The daily intake of ethanol was calculated as follows: the amount of each alcoholic beverage consumed per week was multiplied by its alcohol content and divided by 7 [17]. We considered only beer, because it was the only alcoholic beverage reported by consumers. The following parameters were adopted: a can of beer equivalent to $350 \mathrm{~mL}$; a bottle, $600 \mathrm{~mL}$; a glass, $250 \mathrm{~mL}$. We considered the alcohol content of beer to be 5 per cent $(5 \mathrm{~g} / 100 \mathrm{~mL})$ [18] and consumption of more than $15 \mathrm{~g}$ of ethanol/day as excessive consumption [2].

The subjects were questioned about physical activity (past 6 months) and were classified into 4 categories: active (moderated activities $\geq 30$ minutes/session and $\geq 5$ days/ week, or vigorous activities $\geq 20$ minutes/session and $\geq 3$ days/week, or any activity adding up $\geq 150$ minutes/week and $\geq 5$ days/week); irregularly active A (any physical activity $\geq 150$ minutes/week or $\geq 5$ days/week); irregularly active B (any physical activity, but did not reach any criteria recommendation related to frequency and duration); sedentary (did not practice any physical activity at least 10 continuous minutes during the week). This classification was defined according to the eighth version of the International Physical Activity Questionnaire (IPAQ), validated to Brazilian adult women [19]. We also evaluated previous physical activity (at 20 years old), considering the practice or not of occupational, housework, and leisure physical activities.

We considered smokers as those who smoked regularly for at least 1 year [20] and ex-smokers as those who had stopped smoking at least 2 years before the interview date [17].

2.3. Statistical Analysis. Data were analyzed using Statistical Software for Professional 8.0 (Stata Corp., College Station, TX, USA). The normality test for quantitative variables was performed using normal curves in the Stata software. Variables were analyzed in the whole sample, without considering the menopausal status, like found in some studies [2123], and because some controls did not know about their menopausal status, due to the surgical extraction of their womb.

In bivariate analyses, to compare the 2 groups (case and control) in relation to quantitative variables, we applied Student's $t$-test (parametric distribution) and the Mann Whitney test (nonparametric distribution). Regarding the qualitative variables, we used the chi-square test or Fisher's exact test to compare case and control groups, according to frequency distribution. For all variables related to outcome, we calculated the Wald statistic and the odds ratio (OR), with a significance level of $5 \%$ and a confidence interval
(CI) of $95 \%$. All variables with a $P$ value lower than 0.20 for bivariate analyses were included in multivariate analyses. Logistic regression was performed using a hierarchical model structured in 2 levels. Socioeconomic variables, such as education level, per capita income, and area of residence were included in the first level (distal). Height, physical activity, family history of cancer and of breast cancer, bearing children, and number of children were grouped in the second level (proximal). Bearing children and number of children, although considered as demographic variables, were included in the second level because they are influenced by socioeconomic status. Variables whose $P$ value was lower than 0.05 remained in the logistic regression model [24].

\section{Results}

We invited 98 cases and 186 controls to participate in research, but 5 cases $(5.1 \%)$ refused to be interviewed, adding up 279 women (93 cases and 186 controls). The average age among cases was 51.93 years (range 30-83 years) and that among controls was 51.73 years (range 28-81 years). There were no significant differences between the case and control groups in relation to socioeconomic, gynecological, and anthropometric variables. The median family income per capita was lower than the Brazilian minimum wage ( $\mathrm{R} \$$ 510 per month, approximately US\$300), being US\$ 147 for cases (range US\$ $0-1,470$ ) and US\$ 200 for controls (range US\$ 0-1,029) (Table 2).

Education level, per capita income, area of residence, family history of any kind of cancer, and family history of breast cancer in the first degree were significantly associated with breast cancer in the bivariate analysis (Table 3 ).

Anthropometric and lifestyle variables, such as alcohol consumption, smoking habit, and physical activity, are shown in Table 3. Physical activity (past 6 months) and previous leisure physical activity (at 20 years old) were associated significantly with breast cancer in the bivariate analysis (Table 4).

We considered the following variables in the multivariate analysis: education level, per capita income, area of residence, bearing children, number of children, family history of cancer (any type), history of breast cancer, height, physical activity (past 6 months), and previous occupational and leisure physical activities. After adjusting the OR values, per capita income, area of residence, family history of breast cancer, physical activity (past 6 months), and previous leisure physical activity remained associated with breast cancer (Table 5).

Per capita income equal to or lower than $1 / 2$ Brazilian minimum wage $(\mathrm{OR}=1.88 ; 95 \% \mathrm{CI}=1.06-3.29)$, residence in rural area $(\mathrm{OR}=4.93 ; 95 \% \mathrm{CI}=1.65-14.73)$, and presence of family history of breast cancer $(\mathrm{OR}=5.38 ; 95 \% \mathrm{CI}=$ 1.46-19.93) were considered risk factors for breast cancer. Active women were at lower risk of developing breast cancer, compared to sedentary women $(\mathrm{OR}=0.23 ; \mathrm{CI}=0.10-0.55)$, and that ones who had practiced leisure physical activity at young age (20 years-old) were less likely to develop the disease, compared to who had ever practiced $(\mathrm{OR}=0.13$; $\mathrm{CI}=0.03-0.54)$ (Table 5). 
TABLE 2: Socioeconomic, gynecological, and anthropometric variables of women with breast cancer (cases) and respective controls, from Midwest of Brazil (2008-2010).

\begin{tabular}{|c|c|c|c|c|c|}
\hline \multirow{2}{*}{ Variable } & \multicolumn{2}{|c|}{ Cases $(n=93)$} & \multicolumn{2}{|c|}{ Controls $(n=186)$} & \multirow{2}{*}{$P$ value* } \\
\hline & Mean & $\mathrm{SD}$ & Mean & $\mathrm{SD}$ & \\
\hline Age (years) & 51.93 & 10.07 & 51.77 & 9.73 & 0.897 \\
\hline Height $(\mathrm{cm})$ & 1.55 & 0.05 & 1.55 & 0.06 & 0.570 \\
\hline Current body mass index (BMI) $\left(\mathrm{kg} / \mathrm{m}^{2}\right)$ & 27.14 & 5.44 & 26.84 & 4.53 & 0.623 \\
\hline Waist circumference $(\mathrm{cm})$ & 86.94 & 11.86 & 86.62 & 10.15 & 0.819 \\
\hline \multirow[t]{2}{*}{ Adult weight gain $(\mathrm{kg})$} & 16.94 & 11.65 & 15.65 & 10.51 & 0.416 \\
\hline & \multicolumn{2}{|c|}{ Median } & \multicolumn{2}{|c|}{ Median } & $P$ value** \\
\hline Per capita income (US\$) & \multicolumn{2}{|c|}{147.00} & \multicolumn{2}{|c|}{200.00} & 0.059 \\
\hline $\begin{array}{l}\text { Body mass index }(\mathrm{BMI})\left(\mathrm{kg} / \mathrm{m}^{2}\right) \text { at } 20 \text { years } \\
\text { old }\end{array}$ & \multicolumn{2}{|c|}{21.91} & \multicolumn{2}{|c|}{21.35} & 0.369 \\
\hline Age at menarche (years) & \multicolumn{2}{|c|}{13} & \multicolumn{2}{|c|}{13} & 0.283 \\
\hline Age at menopause (years) & \multicolumn{2}{|c|}{50} & \multicolumn{2}{|c|}{48} & 0.115 \\
\hline Age at first full pregnancy (years) & \multicolumn{2}{|c|}{21} & \multicolumn{2}{|c|}{20} & 0.099 \\
\hline Number of children & \multicolumn{2}{|c|}{3} & \multicolumn{2}{|c|}{3} & 0.719 \\
\hline Total breastfeeding (months) & \multicolumn{2}{|c|}{24} & \multicolumn{2}{|c|}{28} & 0.557 \\
\hline
\end{tabular}

${ }^{*}$ Student's $t$-test. ** Mann-Whitney test. SD: standard deviation.

\section{Discussion}

The sample was very homogeneous concerning socioeconomic, anthropometric, and gynecological variables (Table 2 ). This can be explained by the fact that all interviews were conducted with users of public hospitals, which serve a quite similar population. Women in this sample are of low socioeconomic status, which makes up $29.3 \%$ of Brazilian Midwest families with a per capita income of 0.5-1.0 minimum Brazilian wage [25].

In Table 6, we have summarized the findings of the present study, comparing to WCRF and the AICR evidences [2]. Although nutritional status was not significantly associated with breast cancer (Tables 3 and 5), it is important to emphasize that the prevalence of current overweight (BMI $\geq 25 \mathrm{~kg} / \mathrm{m}^{2}$ ) in both groups (cases and controls) was greater than $60 \%$, and the prevalence of obesity $\left(\mathrm{BMI} \geq 30 \mathrm{~kg} / \mathrm{m}^{2}\right.$ ) was approximately $28 \%$ among cases and 24\% among controls. These values are higher than those found in Brazil, since the proportion of obesity in adult Brazilian women, between 2008 and 2009, was 16.9\% [26]. Obesity statistic found in this sample is troubling, because excessive body fat can promote chronic diseases such as type 2 diabetes and increase the level of proinflammatory substances that may enhance carcinogenesis [2]. The prevalence of excessive alcoholic drinking intake was low, under 3\%, for both cases and controls (Table 4), and may be related with the low socioeconomic status of the sample.

In the present study, we found that having a low per capita income (under $1 / 2$ Brazilian minimum wage) and living in a rural area were risk factors for breast cancer (Table 5). One possible explanation for these findings may be the lesser access to health care and health information of poor women who live in rural areas. Nevertheless, previous studies report that breast cancer is positively associated with urbanization and high socioeconomic status [2-4]. These associations are mainly due to variation in known risk factors, such as late pregnancy and not bearing children, found in women from urban and high-income areas [3].

It should be added that approximately $2 / 3$ of Brazilian population is exposed to pesticides, and the most vulnerable group to this exposure is rural workers [27]. According to Peres, Peres et al. [27], rural workers have low health risk perception related to the use of pesticides. The indiscriminate use of these substances by the rural population could explain the occurrence of some cancers. Moreover, in most Brazilian inner cities, including from Goiás State, a large proportion of women is from rural area, where there are no reference breast services. So that, suspected breast cancer cases move up to capital cities to receive health attendance. Furthermore, it should be emphasized that Goiânia's urbanization process was initiated in 1950 and occurred quickly, which was called "demographic explosion." However, this urbanization was not followed by industrialization [28]. Thus, this population does not have the same characteristics as urban areas in developed countries. Besides, the Brazilian epidemiological transition model, called "transition polarized model," is different from the high-income countries models, named "classic or occidental transition model." In the "transition polarized model," both chronic and infectious diseases coexist as important cause of death, and the decrease in mortality rate is slower. In the "classic or occidental transition model," there is the prevalence of chronic diseases and the mortality rate decreases progressively. Therefore, risk factors may differ according to the epidemiological profile of each population $[9,29]$.

We also found that family history of breast cancer in first degree is a risk factor for breast cancer (Table 5), and this result is reinforced by other ones $[12,30]$. According to 
TABLE 3: Distribution of socioeconomic and gynecological variables in breast cancer women (cases) and their control subjects, from Midwest of Brazil (2008-2010).

\begin{tabular}{|c|c|c|c|c|c|c|}
\hline \multirow{2}{*}{ Variable* } & \multicolumn{2}{|c|}{ Cases $(n=93)$} & \multicolumn{2}{|c|}{ Controls $(n=186)$} & \multirow{2}{*}{ Crude OR (95\% CI) } & \multirow{2}{*}{$P$ value ${ }^{* *}$} \\
\hline & $n$ & $\%$ & $n$ & $\%$ & & \\
\hline \multicolumn{7}{|l|}{ Age (years) } \\
\hline$<50$ & 40 & 43.01 & 72 & 38.71 & 1.00 & - \\
\hline$\geq 50$ & 53 & 56.99 & 114 & 61.29 & $0.84(0.50-1.39)$ & 0.490 \\
\hline \multicolumn{7}{|l|}{ Education level } \\
\hline Did not study & 12 & 12.90 & 9 & 4.84 & 1.00 & - \\
\hline$\leq$ Primary education & 59 & 63.44 & 133 & 71.50 & $0.33(0.13-0.83)$ & 0.019 \\
\hline$\geq$ High school & 22 & 23.66 & 44 & 23.66 & $0.37(0.14-1.02)$ & 0.056 \\
\hline \multicolumn{7}{|l|}{ Per capita income (US\$) } \\
\hline$>1 / 2$ Brazilian minimum wage & 43 & 46.24 & 105 & 60 & 1.00 & - \\
\hline$\leq 1 / 2$ Brazilian minimum wage & 50 & 53.76 & 70 & 40.00 & $1.74(1.05-2.89)$ & 0.032 \\
\hline \multicolumn{7}{|l|}{ Area of residence } \\
\hline Urban & 67 & 83.75 & 155 & 96.27 & 1.00 & - \\
\hline Rural & 13 & 16.25 & 6 & 3.73 & $5.01(1.82-13.74)$ & 0.002 \\
\hline \multicolumn{7}{|l|}{ Bearing children } \\
\hline Yes & 89 & 95.70 & 169 & 90.86 & 1.00 & - \\
\hline No & 4 & 4.30 & 17 & 9.14 & $0.45(0.14-1.37)$ & 0.158 \\
\hline \multicolumn{7}{|l|}{ Number of children } \\
\hline Nulliparity & 4 & 4.30 & 17 & 9.14 & 1.00 & - \\
\hline 1-3 children & 62 & 66.67 & 108 & 58.06 & $2.44(0.78-7.58)$ & 0.123 \\
\hline$>3$ children & 27 & 29.03 & 61 & 32.80 & $1.88(0.58-6.12)$ & 0.294 \\
\hline \multicolumn{7}{|l|}{ Total breastfeeding (months) } \\
\hline Never & 4 & 4.30 & 3 & 1.64 & 1.00 & - \\
\hline$\leq 6$ & 12 & 12.90 & 21 & 11.48 & $0.43(0.08-2.25)$ & 0.316 \\
\hline $7-12$ & 10 & 10.75 & 20 & 10.93 & $0.37(0.07-2.01)$ & 0.252 \\
\hline$>12$ & 67 & 72.04 & 139 & 75.96 & $0.36(0.79-1.66)$ & 0.191 \\
\hline \multicolumn{7}{|l|}{ Age at first pregnancy (years) } \\
\hline$\leq 30$ & 83 & 93.26 & 155 & 92.81 & 1.00 & - \\
\hline$>30$ & 6 & 6.74 & 12 & 7.19 & $0.93(0.34-2.58)$ & 0.895 \\
\hline \multicolumn{7}{|l|}{ Age at menarche (years) } \\
\hline$<12$ (early) & 13 & 14.94 & 28 & 15.30 & 1.00 & - \\
\hline$\geq 12$ (usual) & 74 & 85.06 & 155 & 84.70 & $1.02(0.50-2.09)$ & 0.939 \\
\hline \multicolumn{7}{|l|}{ Age at menopause (years) } \\
\hline$<55$ (usual) & 34 & 91.89 & 111 & 92.50 & 1.00 & - \\
\hline$\geq 55$ (late) & 3 & 8.11 & 9 & 7.50 & $1.09(.28-4.25)$ & 0.903 \\
\hline \multicolumn{7}{|l|}{ Family history of cancer } \\
\hline No & 30 & 32.26 & 94 & 50.54 & 1.00 & - \\
\hline Yes & 63 & 67.74 & 92 & 49.46 & $2.14(1.27-3.61)$ & 0.004 \\
\hline \multicolumn{7}{|l|}{$\begin{array}{l}\text { Family history of breast cancer } \\
\text { (mother/sisters) }\end{array}$} \\
\hline No & 85 & 91.40 & 182 & 97.85 & 1.00 & - \\
\hline Yes & 8 & 8.60 & 4 & 2.15 & $4.28(1.25-14.61)$ & 0.020 \\
\hline
\end{tabular}

OR: odds ratio and CI: confidence interval.

* Per capita income: Brazilian minimum wage corresponds to approximately US\$ 300; 11 control subjects did not indicate their per capita income; area of residence: information is unavailable for 13 cases and 25 controls; total breastfeeding: 3 controls did not indicate their breastfeeding time; age at first pregnancy: 4 cases and 19 controls did not have children or did not indicate their age at first pregnancy; age at menarche: 6 cases and 3 controls did not indicate their age at menarche; age at menopause: 12 cases and 11 controls did not indicate their age at menopause; 44 cases and 55 controls were premenopausal.

** Wald statistic. 
TABLE 4: Distribution of anthropometric and lifestyle variables in breast cancer women (cases) and control subjects, from Midwest of Brazil (2008-2010).

\begin{tabular}{|c|c|c|c|c|c|c|}
\hline \multirow{2}{*}{ Variable* } & \multicolumn{2}{|c|}{ Cases $(n=93)$} & \multicolumn{2}{|c|}{ Controls $(n=186)$} & \multirow{2}{*}{ Crude OR (95\% CI) } & \multirow{2}{*}{$P$ value** } \\
\hline & $n$ & $\%$ & $n$ & $\%$ & & \\
\hline \multicolumn{7}{|l|}{ Adult weight gain $(\mathrm{kg})$} \\
\hline$\leq 5$ & 10 & 14.08 & 14 & 9.52 & 1.00 & - \\
\hline $5.01-10$ & 11 & 15.49 & 33 & 22.45 & $0.47(0.16-1.35)$ & 0.159 \\
\hline$>10$ & 50 & 70.43 & 100 & 68.03 & $0.71(0.29-1.71)$ & 0.441 \\
\hline \multicolumn{7}{|c|}{ Current nutritional status } \\
\hline Eutrophic & 38 & 40.86 & 70 & 37.63 & 1.00 & - \\
\hline Preobesity & 29 & 31.18 & 71 & 38.17 & $0.75(0.42-1.35)$ & 0.341 \\
\hline Obesity & 26 & 27.96 & 45 & 24.19 & $1.06(0.57-1.98)$ & 0.845 \\
\hline \multicolumn{7}{|c|}{ Nutritional status (at 20 years old) } \\
\hline Eutrophic & 67 & 94.37 & 134 & 91.16 & 1.00 & - \\
\hline Overweight & 4 & 5.63 & 13 & 8.84 & $0.61(0.19-1.96)$ & 0.411 \\
\hline \multicolumn{7}{|l|}{ Waist circumference $(\mathrm{cm})$} \\
\hline$<80$ & 29 & 31.18 & 47 & 25.27 & 1.00 & - \\
\hline$\geq 80$ & 64 & 68.82 & 139 & 74.73 & $0.75(0.43-1.29)$ & 0.296 \\
\hline \multicolumn{7}{|l|}{ Height $(\mathrm{cm})$} \\
\hline$<160$ & 78 & 83.87 & 138 & 74.19 & 1.00 & - \\
\hline$\geq 160$ & 15 & 16.13 & 48 & 25.81 & $0.55(0.29-1.05)$ & 0.071 \\
\hline \multicolumn{7}{|c|}{ Alcohol beverage consumption } \\
\hline Absent or moderate & 90 & 97.83 & 184 & 98.92 & 1.00 & - \\
\hline Excessive & 2 & 2.17 & 2 & 1.08 & $2.04(0.28-14.75)$ & 0.478 \\
\hline \multicolumn{7}{|l|}{ Smoking habit } \\
\hline Not smoker & 53 & 56.99 & 108 & 58.06 & 1.00 & - \\
\hline Ex-smoker & 26 & 27.96 & 46 & 24.73 & $1.15(0.64-2.06)$ & 0.634 \\
\hline Smoker & 14 & 15.05 & 32 & 17.20 & $0.89(0.44-1.81)$ & 0.751 \\
\hline \multicolumn{7}{|c|}{ Physical activity (past 6 months) } \\
\hline Sedentary & 34 & 36.56 & 24 & 12.90 & 1.00 & - \\
\hline Irregularly active B & 16 & 17.20 & 33 & 17.74 & $0.34(0.15-0.76)$ & 0.008 \\
\hline Irregularly active A & 9 & 9.68 & 39 & 20.97 & $0.16(0.07-0.40)$ & 0.000 \\
\hline Active & 34 & 36.56 & 90 & 48.39 & $0.27(0.14-0.51)$ & 0.000 \\
\hline \multicolumn{7}{|c|}{ Occupational physical activity (at 20 years old) } \\
\hline No & 57 & 72.15 & 99 & 61.88 & 1.00 & - \\
\hline Yes & 22 & 27.85 & 61 & 38.13 & $0.62(0.35-1.12)$ & 0.118 \\
\hline \multicolumn{7}{|c|}{ Housework physical activity (at 20 years old) ${ }^{\mathrm{f}}$} \\
\hline No & 13 & 16.46 & 20 & 12.50 & 1.00 & - \\
\hline Yes & 66 & 83.54 & 140 & 87.50 & $0.72(0.34-1.55)$ & 0.406 \\
\hline \multicolumn{7}{|c|}{ Leisure physical activity (at 20 years old) ${ }^{\mathrm{f}}$} \\
\hline No & 74 & 93.67 & 119 & 74.38 & 1.00 & - \\
\hline Yes & 5 & 6.33 & 41 & 25.62 & $0.20(0.07-0.52)$ & 0.001 \\
\hline
\end{tabular}

OR: odds ratio and CI: confidence interval.

*Adult weight gain: 22 cases and 39 controls did not indicate their weight at 20 years old; current nutritional status: eutrophic—body mass index (BMI) = $18.4 \mathrm{~kg} / \mathrm{m}^{2}$ to $24.9 \mathrm{~kg} / \mathrm{m}^{2}$; preobesity-BMI $=25 \mathrm{~kg} / \mathrm{m}^{2}$ to $29.9 \mathrm{~kg} / \mathrm{m}^{2}$; obesity-BMI $\geq 30 \mathrm{~kg} / \mathrm{m}^{2}$ [11]; alcohol beverage consumption: 1 case did not indicate alcohol beverage intake; occupational physical activity: information unavailable for 14 cases and 26 controls.

$* *$ Wald statistic.

the "theory of two stages" in the genetic determinism of carcinogenesis, it is necessary that mutations occur at the same locus of homologous chromosomes for the development of a malignant tumor. Thus, in nonhereditary cases (also called sporadic cases), 2 mutagenic processes are required, whereas, in hereditary cases, 1 genetic mutation already exists and only 1 more mutation in the other chromosome is necessary [31]. According to Brandt et al. [12], 15-20\% of breast cancer 
TABle 5: Per capita income, area of residence, physical activity, and family history of breast cancer of women with breast cancer (cases) and respective controls, from Midwest of Brazil (2008-2010).

\begin{tabular}{|c|c|c|c|c|c|c|}
\hline \multirow{2}{*}{ Variable* } & \multicolumn{2}{|c|}{ Cases $(n=93)$} & \multicolumn{2}{|c|}{ Controls $(n=186)$} & \multirow{2}{*}{ Adjusted OR (95\% CI) } & \multirow{2}{*}{$P$ value** } \\
\hline & $n$ & $\%$ & $n$ & $\%$ & & \\
\hline \multicolumn{7}{|l|}{ First level } \\
\hline \multicolumn{7}{|l|}{ Per capita income (US\$) } \\
\hline$>1 / 2$ Brazilian minimum wage & 43 & 46.24 & 105 & 60.00 & 1.00 & - \\
\hline$\leq 1 / 2$ Brazilian minimum wage & 50 & 53.76 & 70 & 40.00 & $1.87(1.06-3.29)$ & 0.031 \\
\hline \multicolumn{7}{|l|}{ Area of residence } \\
\hline Urban & 67 & 83.75 & 155 & 96.27 & 1.00 & - \\
\hline Rural & 13 & 16.25 & 6 & 3.73 & $4.93(1.65-14.73)$ & 0.004 \\
\hline \multicolumn{7}{|l|}{ Second level } \\
\hline \multicolumn{7}{|l|}{ Family history of breast cancer } \\
\hline No & 85 & 91.40 & 182 & 97.85 & 1.00 & - \\
\hline Yes & 8 & 8.60 & 4 & 2.15 & $5.38(1.46-19.93)$ & 0.012 \\
\hline \multicolumn{7}{|l|}{ Physical activity (past 6 months) } \\
\hline Sedentary & 34 & 36.56 & 24 & 12.90 & 1.00 & - \\
\hline Irregularly active B & 16 & 17.20 & 33 & 17.74 & $0.50(0.18-1.37)$ & 0.178 \\
\hline Irregularly active A & 9 & 9.68 & 39 & 20.97 & $0.26(0.09-0.77)$ & 0.016 \\
\hline Active & 34 & 36.56 & 90 & 48.39 & $0.23(0.10-0.55)$ & 0.001 \\
\hline \multicolumn{7}{|c|}{ Leisure physical activity (at 20 years old) } \\
\hline No & 74 & 93.67 & 119 & 74.38 & 1.00 & - \\
\hline Yes & 5 & 6.33 & 41 & 25.62 & $0.13(0.03-0.54)$ & 0.005 \\
\hline
\end{tabular}

OR: odds ratio and CI: confidence interval; multivariate analyses adjusted for educational level, per capita income, area of residence, bearing children, number of children, height, physical activity (past 6 months), previous occupational and leisure physical activity, family history of cancer (any type), and family history of breast cancer (mother/sisters).

* Per capita income: Brazilian minimum wage corresponds to approximately US\$ 300, 11 control subjects did not indicate their per capita income; area of residence: information is unavailable for 13 cases and 25 controls.

** Wald statistic.

cases are associated with family history of breast cancer, but only $15 \%$ can be explained by mutations in the BRCA1 and $B R C A 2$ genes, known tumor suppressors. A woman who carries a mutation in BRCA-1 has a risk of $60-80 \%$ for developing breast cancer [12,31].

Regarding physical activity, we found that women who practiced at least 150 minutes/week and/or $\geq 5$ days/week of physical activity were at lower risk of developing breast cancer, compared to sedentary women. Moreover, that ones who practiced leisure physical activity at young age (20 years old) were also at lower risk, compared to that women who did not practice leisure activity. These results show that physical activity, in general, may protect against breast cancer. This protective effect is supported by WCRF and AICR's report and by other case-control studies [2, 58]. This result is important because WCRF and AICR [2] concluded that the protective effect of physical activity is not convincing yet (probable in postmenopausal women, but limited in premenopausal women), and our study supports this evidence, which may increase the consistency of this association (Table 6).

Regular physical activity probably has a protective effect on breast cancer by delaying menarche, promoting irregular and anovulatory cycles, reducing serum estrogen, increasing globulins that bind to sex hormones, reducing inflammation, improving immune function, and helping to control weight and to improve sensitivity to insulin $[2,6]$. Considering the importance of physical activity practice in prevention of breast cancer and other chronic diseases, and that health is a determinant key of development and a precursor of economic growth, it is necessary to perform programs aimed at promoting health lifestyle. To implement these policies, it is necessary the collaboration between the health sector and other key sectors, such as education, urban planning, transportation, and communication [32].

The lack of an association of some variables with breast cancer can be explained partially by the recall bias, which is very common in case-control studies. Another difficulty of case-control studies is the time required to consider exposure factors. Some studies [22, 33] considered exposure factors over 1 year. In the present study, we adopted 6 months preceding the interview to minimize memory bias. Although the exposure time considered in this study was shorter than most previous case-control studies, we interviewed cases immediately after the positive diagnosis of breast cancer to avoid misconceptions about the exposure time. In fact, it 
TABLE 6: Findings from the case-control study (2011) of Midwest, Brazil, compared to World Cancer Research Fund and American Institute for Cancer Research evidences (2007) [2].

\begin{tabular}{|c|c|c|}
\hline New data & $\begin{array}{l}\text { Reinforce the } \\
\text { literature }\end{array}$ & Not confirmed \\
\hline $\begin{array}{l}\text { Low per capita } \\
\text { income (risk factor) }\end{array}$ & $\begin{array}{l}\text { Physical activity } \\
\text { (protective factor) }\end{array}$ & Breastfeeding \\
\hline \multirow[t]{4}{*}{$\begin{array}{l}\text { Residence in rural } \\
\text { area (risk factor) }\end{array}$} & $\begin{array}{l}\text { Family history of } \\
\text { breast cancer in first } \\
\text { degree (risk factor) }\end{array}$ & $\begin{array}{l}\text { Gynecological variables } \\
\text { (bearing children, age at } \\
\text { first pregnancy, age at } \\
\text { menarche, age at } \\
\text { menopause) }\end{array}$ \\
\hline & & $\begin{array}{l}\text { Anthropometric } \\
\text { variables (adult weight } \\
\text { gain, nutritional status, } \\
\text { waist circumference, } \\
\text { height) }\end{array}$ \\
\hline & & $\begin{array}{l}\text { Alcohol beverage } \\
\text { consumption }\end{array}$ \\
\hline & & Smoking habit \\
\hline
\end{tabular}

represents a great strength of the present study, since in the other studies previously cited $[22,33]$, cases were interviewed 3-4 months after diagnosis.

We recommend that other breast cancer case-control studies are conducted on populations of higher socioeconomic status from the same region of Brazil. The risk and protective factors published by WCRF and AICR [2] may apply better to such segment of the population, because their lifestyles are more similar to those from developed countries, where most case-control and cohort studies are performed. Furthermore, it is necessary to better explore the question of area of residence to clarify the association of this variable with breast cancer in the present population.

This investigation is the first case-control study on the risk and protective factors for breast cancer in a population from Midwest of Brazil. Findings from our research reinforce the associations between physical activity and family history of breast cancer, in first degree, and breast cancer. Moreover, our results reveal new data that can contribute to elucidate determinant factors for breast cancer, and to prevent this disease in epidemiological transition countries, such as Brazil (Table 6).

\section{Conclusions}

Low per capita income, living in a rural area, and family history of breast cancer are risk factors for breast cancer, whereas practicing physical activity, including at 20 years old, is a protective factor for the disease in women from Midwest of Brazil.

\section{Acknowledgments}

The authors are grateful to the Federal University of Goiás (UFG) for the scholarship. They thank physicians and employees of the hospitals involved in the study for assistance with data collection and, especially, the women who, even with the difficult diagnosis of breast cancer, agreed to participate in this study.

\section{References}

[1] Ministério da Saúde, Instituto Nacional de Câncer, Políticas e Ações Para Prevenção do Câncer no Brasil: Alimentação, Nutrição e Atividade Física, INCA, Rio de Janeiro, Brazil, 2009.

[2] World Cancer Research Fund (WCRF), American Institute for Cancer Research (AICR), Food, Nutrition, Physical Activity, and the Prevention of Cancer: A Global Perspective, AICR, Washington, DC, USA, 2007.

[3] J. L. Kelsey, "Breast cancer epidemiology: summary and future directions," Epidemiologic Reviews, vol. 15, no. 1, pp. 256-263, 1993.

[4] Ministério da Saúde (Brasil), Estimativa 2010: Incidência de Câncer no Brasil, INCA, Rio de Janeiro, Brazil, 2009.

[5] M. E. Schmidt, K. Steindorf, E. Mutschelknauss et al., "Physical activity and postmenopausal breast cancer: effect modification by breast cancer subtypes and effective periods in life," Cancer Epidemiology Biomarkers and Prevention, vol. 17, no. 12, pp. 3402-3410, 2008.

[6] B. Peplonska, J. Lissowska, T. J. Hartman et al., "Adulthood lifetime physical activity and breast cancer," Epidemiology, vol. 19, no. 2, pp. 226-236, 2008.

[7] V. Bissonauth, B. Shatenstein, E. Fafard et al., "Weight history, smoking, physical activity and breast cancer risk among French-Canadian women non-carriers of more frequent BRCA1/2 mutations," Journal of Cancer Epidemiology, vol. 2009, Article ID 748367, 11 pages, 2009.

[8] M. L. Slattery, S. Edwards, M. A. Murtaugh et al., "Physical activity and breast cancer risk among women in the Southwestern United States," Annals of Epidemiology, vol. 17, no. 5, pp. 342-353, 2007.

[9] J. Frenk, "The epidemiological transition in Latin America," Boletin de la Oficina Sanitaria Panamericana, vol. 111, no. 6, pp. 485-496, 1991.

[10] V. Hanf and U. Gonder, "Nutrition and primary prevention of breast cancer: foods, nutrients and breast cancer risk," European Journal of Obstetrics Gynecology and Reproductive Biology, vol. 123, no. 2, pp. 139-149, 2005.

[11] World Health Organization, "Obesity: preventing and managing the global epidemic," WHO Technical Report Series 894, WHO, Geneva, Switzerland, 2000.

[12] B. Brandt, S. Hermann, K. Straif, N. Tidow, H. Buerger, and J. Chang-Claude, "Modification of breast cancer risk in young women by a polymorphic sequence in the egfr gene," Cancer Research, vol. 64, no. 1, pp. 7-12, 2004.

[13] M. D. R. G. Peixoto, E. T. Monego, V. P. Alexandre, R. G. M. De Souza, and E. C. De Moura, "Surveillance of risk factors for chronic diseases through telephone interviews: experience in Goiânia, Goiás State, Brazil," Cadernos de Saúde Pública, vol. 24, no. 6, pp. 1323-1333, 2008.

[14] P. H. Lahmann, M. Schulz, K. Hoffmann et al., "Long term weight change and breast cancer risk: the European prospective investigation into cancer and nutrition (EPIC)," British Journal of Cancer, vol. 93, no. 5, pp. 582-589, 2005.

[15] T. G. Lohman, A. F. Roche, and R. Martorell, Anthropometric Standardization Reference Manual, Human Kinetics, Champaign, Ill, USA, 1988. 
[16] J. P. Habicht, "Estandarizacion de metodos epidemiologicos cuantitativos sobre el terreno," Boletín de la Oficina Sanitaria Panamericana, vol. 76, no. 5, pp. 375-381, 1974.

[17] L. M. Brown, G. Gridley, A. H. Wu et al., "Low level alcohol intake, cigarette smoking and risk of breast cancer in AsianAmerican women," Breast Cancer Research and Treatment, vol. 120, no. 1, pp. 203-210, 2010.

[18] C. Loguercio, C. Tuccillo, A. Federico, V. Fogliano, C. Del Vecchio Blanco, and M. Romano, "Alcoholic beverages and gastric epithelial cell viability: effect on oxidative stressinduced damage," Journal of Physiology and Pharmacology, vol. 60, supplement 1, pp. 87-92, 2009.

[19] S. M. Matsudo, V. R. Matsudo, T. Araújo et al., "Physical activity level of São Paulo State population: an analysis based on gender, age, socio-economic status, demographics and knowledge," Revista Brasileira de Ciência e Movimento, vol. 10, no. 4, pp. 41-50, 2002.

[20] C. Magnusson, S. Wedrén, and L. U. Rosenberg, "Cigarette smoking and breast cancer risk: a population-based study in Sweden," British Journal of Cancer, vol. 97, no. 9, pp. 12871290, 2007.

[21] S. Shahar, R. M. Salleh, A. R. Ghazali, P. B. Koon, and W. N. Wan Mohamud, "Roles of adiposity, lifetime physical activity and serum adiponectin in occurrence of breast cancer among Malaysian women in Klang Valley," Asian Pacific Journal of Cancer Prevention, vol. 11, no. 1, pp. 61-66, 2010.

[22] F. Bessaoud and J. P. Daurès, "Patterns of alcohol (especially wine) consumption and breast cancer risk: a case-control study among a population in Southern France," Annals of Epidemiology, vol. 18, no. 6, pp. 467-475, 2008.

[23] M. Sanderson, G. Peltz, A. Perez et al., "Diabetes, physical activity and breast cancer among Hispanic women," Cancer Epidemiology, vol. 34, no. 5, pp. 556-561, 2010.

[24] R. G. Steel and J. H. Torrie, Principles and Procedures of Statistics: A Biometrical Approach, McGraw-Hill, New York, NY, USA, 1996.

[25] Instituto Btasileiro de Geografia e Estatística (IBGE), "Síntese de indicadores sociais (2008)," http://www.ibge.gov.br/ home/estatistica/populacao/condicaodevida/indicadoresminimos/sinteseindicsociais2008/default.shtm.

[26] Instituto Brasileiro de Geografia e Estatística (IBGE), "Pesquisa de orçamentos familiares 2008-2009," http://www.ibge .gov.br/home/xml/pof_2008_2009.shtm.

[27] F. Peres, B. Rozemberg, and S. R. de Lucca, "Risk perception related to work in a rural community of Rio de Janeiro State, Brazil: pesticides, health, and environment," Cadernos de Saúde Pública, vol. 21, no. 6, pp. 1836-1844, 2005.

[28] L. Palacín and M. A. S. Moraes, História de Goiás, UCG, Goiânia, Brazil, 1994.

[29] L. Huicho, M. Trelles, F. Gonzales, W. Mendoza, and J. Miranda, "Mortality profiles in a country facing epidemiological transition: an analysis of registered data," BMC Public Health, vol. 9, article no. 47, 2009.

[30] S. Tessaro, J. U. Béria, E. Tomasi, and C. G. Victora, "Breastfeeding and breast cancer: a case-control study in Southern Brazil," Cadernos de Saúde Pública, vol. 19, no. 6, pp. 15931601, 2003.

[31] A. G. Knudson, "Two genetic hits (more or less) to cancer," Nature Reviews Cancer, vol. 1, no. 2, pp. 157-162, 2001.

[32] World Health Organization (WHO), Global Strategy on Diet, Physical Activity and Health, WHO, Geneva, Switzerland, 2004.
[33] P. Berstad, H. Ma, L. Bernstein, and G. Ursin, "Alcohol intake and breast cancer risk among young women," Breast Cancer Research and Treatment, vol. 108, no. 1, pp. 113-120, 2008. 


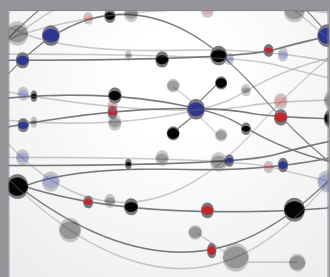

The Scientific World Journal
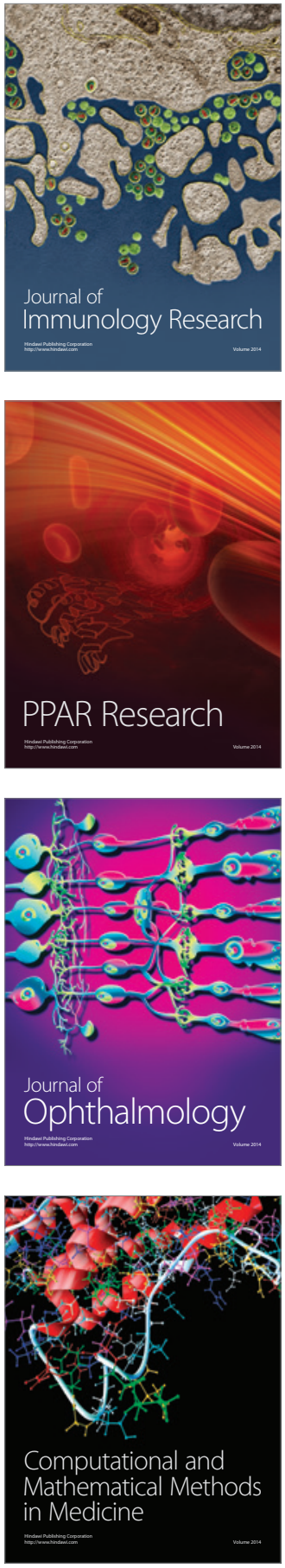

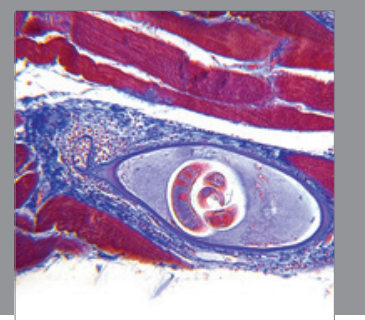

Gastroenterology

Research and Practice
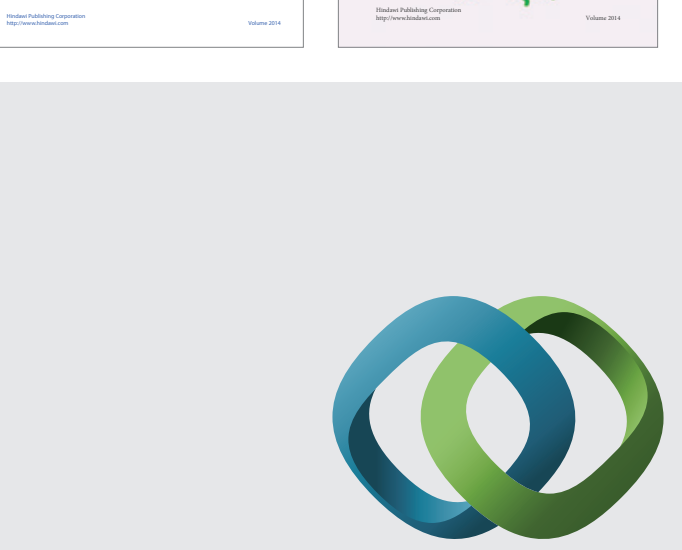

\section{Hindawi}

Submit your manuscripts at

http://www.hindawi.com
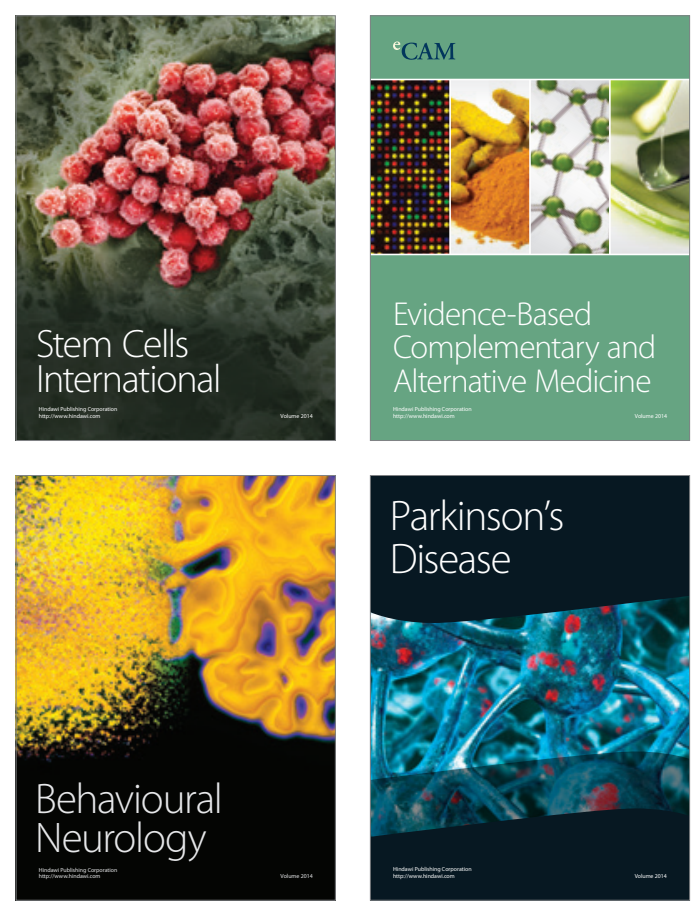

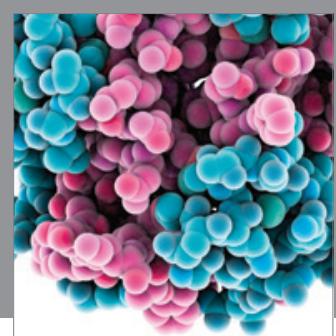

Journal of
Diabetes Research

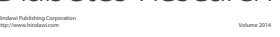

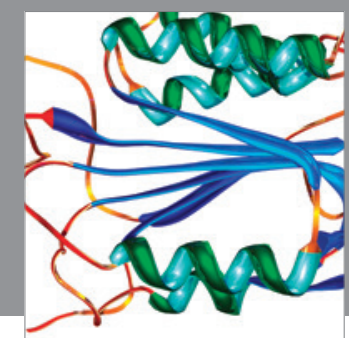

Disease Markers
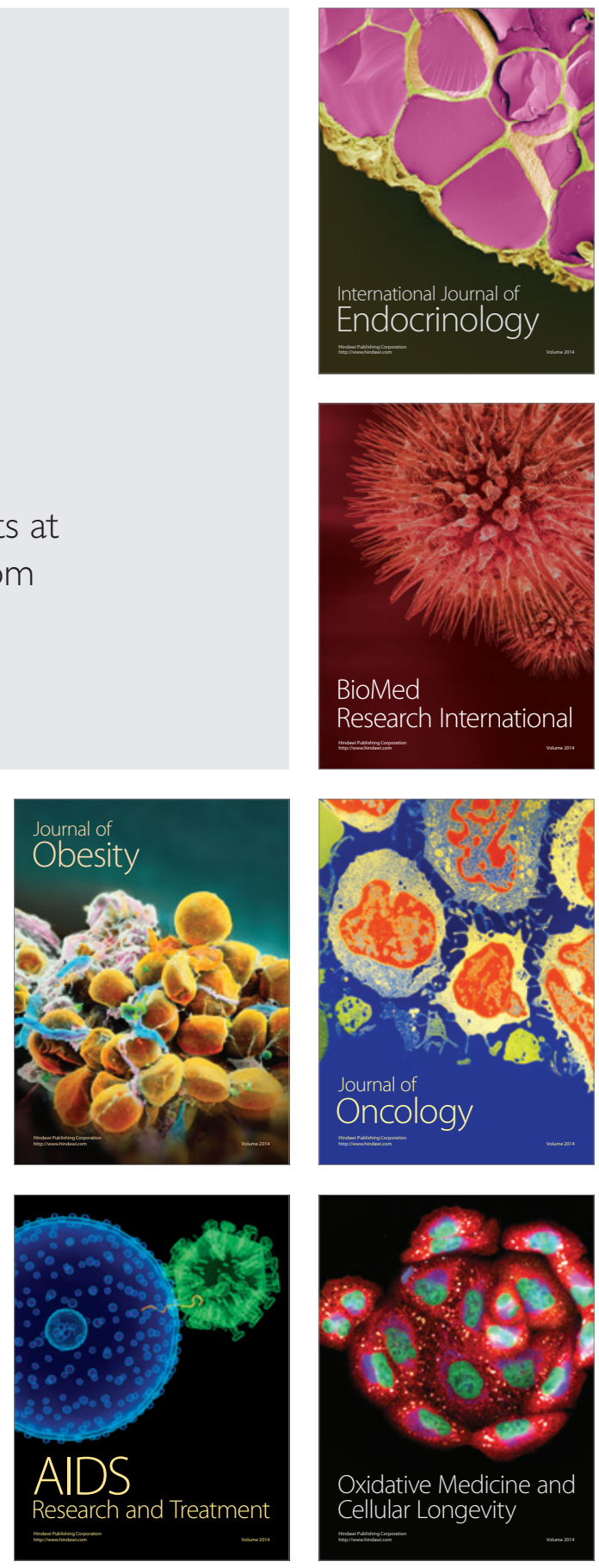